\title{
KEBERLANJUTAN TRADISI BERKONSTRUKSI RUMAH TRADISIONAL DI KAMPUNG ADAT NAMATA KABUPATEN SABU RAIJUA
}

\author{
Yohanes W.D. Kapilawi ${ }^{1}$, Rosvitayati U. Nday $^{2}$, Thomas Kurniawan Dima ${ }^{3}$ \\ ${ }^{1,2,3}$ Prodi Arsitektur, Fakultas Sains dan Teknik, Universitas Nusa Cendana
}

Penulis korespondensi: Yohanes W.D. Kapilawi, yohaneskapilawi@staf.undana.ac.id

Naskah diajukan pada: 19 April 2021

Naskah revisi akhir diterima pada: 02 Agustus 2021

\begin{abstract}
Abstrak
Pemahaman berkonstruksi dalam konteks masyarakat adat merupakan suatu proses aktivitas terkait hubungan sosial kelompok masyarakat adat, lingkungannya serta tradisi yang memiliki keseimbangan dikeseluruhan tahap kegiatan berkonstruksi guna membangun atau memperbaiki huniannya. Salah satu kampung adat di Pulau Sabu yaitu Kampung Adat Namata merupakan kampung tradisional dengan masyarakat adat yang masih mempertahankan tradisi membangun dengan memperhatikan aturan-aturan adat dalam pemanfaatan material konstruksi dan menghargai lingkungannya, walaupun dikelilingi desa modern disekitarnya. Meski tradisi pengambilan dan pengangkutan material mulai hilang namun pemahaman tradisi berkonstruksi tiap struktur masih tetap dipertahankan sehingga menjadi menarik untuk dikaji untuk mengetahui setiap prosesi adat, pemahaman, makna serta tujuan tiap proses berkonstruksi sehingga menjadi rumah adat yang menghargai dan adaptif terhadap lingkungan serta menjadi keberlanjutan berkonstruksi dari budaya arsitektur. Penelitian ini menggunakan metode deskripstif kualitatif, wawancara dan pengamatan terhadap setiap aktivitas tradisi berkonstruksi hingga menjadi rumah adat. Hasil temuan menunjukkan adanya tindakan menghormati mulai dari tata cara ritual penebangan pohon, keberlanjutan tradisi cara pengambilan bahan bangunan hingga penciptaan bentuk bangunan, adanya kearifan lokalitas dalam penggunaan material, penamaan bagian rumah adat menggunakan unsur bahasa lokal serta pemahaman filosofi dan tata cara ritual tiap bagian konstruksi sebagai upaya masyarakat adat untuk menjaga keberlanjutan tata cara berkonstruksi dan keseimbangan lingkungan.
\end{abstract}

Kata-kata Kunci: Kampung Adat Namata, Keberlanjutan, Rumah Tradisonal, Tradisi Berkonstruksi

\section{SUSTAINABILITY OF TRADITIONAL HOUSE CONSTRUCTION IN NAMATA TRADITIONAL VILLAGE, SABU RAIJUA REGENCY}

\begin{abstract}
Construction understanding in indigenous peoples is a social relations activity among indigenous groups, the environment, and traditions that balance all construction activities to build or repair their dwellings. Namata Traditional Village on Sabu Island is a village with indigenous peoples who still maintain the development process tradition and also customary rules in constructing the materials and respecting the environment, even though modern villages surround it. Although taking and transporting materials tradition begins to disappear, constructing tradition understanding of each structure is still maintained. Thus, it is interesting to study the processing,
\end{abstract}


understanding, meaning, and purposing of each construction process to become a traditional house that respects and is adaptive to the environment and become sustainable construction of architectural culture. This study used qualitative descriptive methods, interviews, and observations of every construction tradition until it became a traditional house. The findings show respect actions are starting from tree felling rituals, construction sustainability of taking building materials until creating building forms, local wisdom in using local materials, the local language in naming parts of the traditional house, and philosophical understanding and ritual procedures from each part of the construction as an effort to maintain the construction sustainability procedures and environmental balance.

Keywords: Namata Traditional Village, Sustainability, Traditional Houses, Tradition Constructed

\section{Pendahuluan}

Kampung Namata merupakan salah satu kampung tradisonal yang menyajikan nuansa dari peradaban zaman megalitik. Ditengah kampung tersebut dipenuhi oleh bongkahan batu yang di depannya terdapat altar atau tempat pemujaan dengan batu-batunya tersusun secara rapi. Menurut kepercayaan masyarakat Sabu, batu-batu tersebut dengan sendirinya berada di perkampungan itu yang kemudian terdapat beberapa rumah adat dalam kampung tersebut. Pemahaman berkonstruksi merupakan pengetahuan yang diturunkan dari generasi ke generasi oleh masyarakat kampung adat Namata, hal ini bukan hanya sebagai sebuah wacana alat adat-istiadat saja namun menjadi sesuatu prinsip yang secara terus berkesinambung dan wajib untuk tetap dijalankan. Dalam menafsirkan setiap makna dari keseluruhan ritual adat terutama dalam proses membangun atau berkonstruksi, memiliki keselarasan hubungan antara kehidupan manusia, alam dan yang dipercaya memiliki kedudukan tertinggi dan yang menentukan kehidupan mereka meskipun kampung ini telah dikelilingi kampung modern disekitarnya. Pemahaman berkonstruksi secara tradisi adat, bagi masyarakat menjadi kegiatan yang memang perlu dilakukan untuk mendapatkan keselamatan dan kesejahteraan bagi yang menghuni. Keberlanjutan menurut pemahaman masyarakat tradisional terhadap tradisi berkonstruksi rumah adat, menjadi salah satu bagian dari kebelanjutan budaya dalam konteks berkonstruksi serta berarsitektur yang patut untuk dipertahankan demi keseimbangan hubungan dengan penciptanya.

Menurut Mangunwijaya dalam Manurung (2014), "Namun janganlah hendaknya kita mengira, seolah-olah alasan-alasan gaib, mistis atau magis itu satu-satunya alasan atau pedoman berarsitektur bagi manusia kuno. Mereka pun cerdas dalam menganalisa realita dan penanganan praktis permasalahan permukiman serta bangunan-bangunan”. Hal Ini menunjukkan bahwa, dalam merancang dan membangun arsitektur tradisional di masa lalu, nenek moyang juga memerhatikan dan menganalisis kondisi riil di lapangan dan konteks melingkupinya. Arsitektur tradisional sangat mempertimbangkan bagaimana kondisi alam terkait dengan kelembaban, curah hujan, potensi bencana alam seperti gempa bumi, tsunami dan sebagainya.

Mangunwijaya dalam Manurung (2014) juga mengatakan bahwa "Akan tetapi rumah panggung atau rumah kolong benar-benar merupakan penyelesaian soal berkualitas tinggi”. Rumah panggung merupakan satu keputusan desain yang sangat berpihak pada alam, disamping juga berperan memberikan kenyamanan dan keamanan pada penghuninya. Faktor kelembaban, menjadi satu pertimbangan dalam upaya menciptakan kenyamanan pada rumah panggung. Sementara keamanan dari binatang buas, perang suku, menjadi pertimbangan dalam memutuskan desain rumah panggung. Dalam masyarakat tradisonal, pembangunan arsitektur juga selalu dikaitkan dengan halhal yang bersifat religus dan dianggap suci serta keramat. Ditambahkan oleh Mentayani, dkk (2011) aspek vernakular terdiri dari tiga aspek yaitu (1) aspek teknis terlihat dari ciri menggunakan bahan alami dan teknik berkonstruksi sederhana dengan Menyusun tiang dan balok, (2) aspek budaya dapat 
dilihat dari cara masyrakat mengekspresikan budaya bukan sahja menyangkut fisik bangunan tetapi juga terdapat semangat dan jiwa yang tekandung mengikuti aturan-aturan yang telah diikuti sejak jaman dahulu, serta (3) aspek lingkungan.

Pendapat Ardiani (2015), dalam bukunya yang berjudul "Sutainable Architecture: Arsitektur Berkelanjutan" arti dari pembangunan menurut kamus adalah pembangunan atau pengembangan. Maka arti dari pembangunan berkelanjutan adalah pembangunan yang pada hakekatnya merupakan gangguan terhadap suatu sistem yang sudah ada yang keseimbangannya diubah untuk memperoleh mutu lingkungan yang lebih baik atau lebih tinggi. Hal ini seleras dengan ciri vernakular yang merupakan bangunan dengan keunikan sendiri yang oleh Guiterrez (Mentayani, dkk, 2011) disebabkan oleh karena dibangun secara turun temurun dari ancient tradition, baik deri segi pengatuahan serta metode yang digunakan (trial dan error) yang menyesuaikan kebutuhan, lingkungan serta tetap bertahan hingga sekarang.

Pemahaman akan arsitektur vernakular oleh Anselm (2006; Permana, 2011) yang menyebutkan arsitektur vernakular lebih menekankan pada tradisi serta kondisi sokial-budaya dari masyarakat sebagai ukuran dari kenyamanan. Salah satu contoh terlihat pada proses pembangunan sebuah rumah adat Sumba yang selalu disertai dengan tahapan-tahapan dalam penyelesaian setiap struktur konstruksi rumah (Mross, 1995 dalam Nurdiah dkk, 2013). Demikian pula halnya pada setiap pemasangan bagian-bagian konstruksi rumah selalu diikuti dengan tradisi setempat tentang aturan berkonstruksi (Nurdiah dkk, 2013).

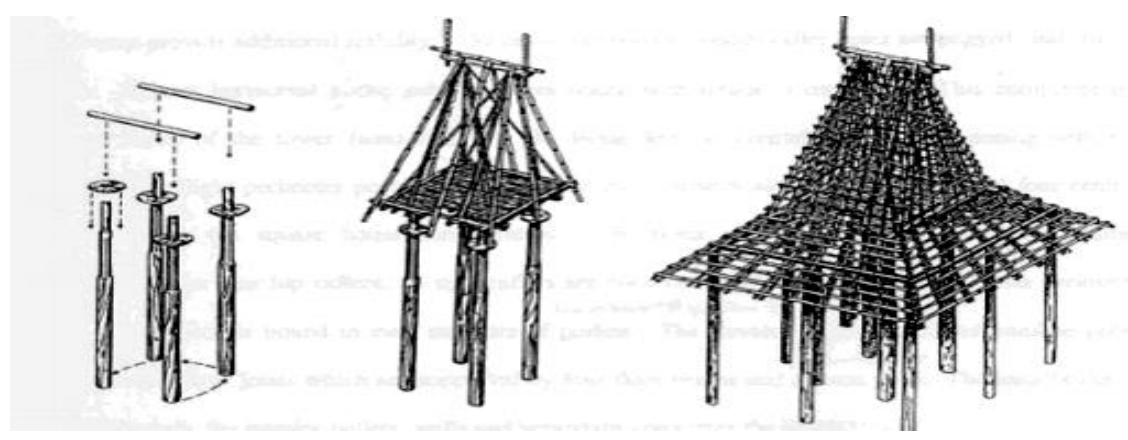

Gambar 1. Proses Pelaksanaan pada Struktur Rangka Rumah Adat Sumba Sumber: Mross, 1995 dalam Nurdiah dkk, 2013

Keberlanjutan berkonstruksi pada masyaratakat Sabu di Kampung Namata hingga saat ini masih terus dipertahankan bukan hanya sebagai wacana adat istiadat saja namun juga sebagai prinsip hidup masyarakat. Sebagian besar tradisi kegiatan berkonstruksi sangat dipertahankan dengan pemahaman kegiatan dilakukan untuk mendapatkan kesejahteraan, keselamatan dan kenyamananan bagi penghuninya. Hal ini kemudian menjadi menarik untuk diteliti oleh sebab beberapa bagian penting dalam tiap elemen tahapan berkonstruksi prosesi adatnya masih terus dipertahankan. Prosesi yang hilang tersebut diantaranya (1) masyarakat sudah tidak lagi mengambil material dari hutan tetapi digantikan dengan material yang diambil dari tetangga maupun masyarakat sektar kampung dan (2) material sudah tidak diangkut oleh manusia tetapi sudah digantikan oleh kendaraan. Prosesi ini hilang akibat dari kampung lain disekitar kampung adat Namata telah menjadi kampung atau desa modern yang tidak menerapkan keberlanjutan berkonstruksi secara adat dan kampung adat Namata menjadi satu-satunya kampung yang masih mempertahankan berkonstruksi dengan ritual adat, sehingga keberlanjutan ini patut untuk dipertahankan.

Penelitian ini bertujuan untuk memaparkan hasil secara obyektif tentang kehidupan masyarakat adat dalam tradisi berkonstruksi pada setiap proses dan makna pembangunan dengan menggunakan material lokal setempat dan gambaran keseimbangan kehidupan masyarakatnya 
dengan alam tempat tinggalnya yang secara tidak langsung dengan bijaknya telah menjaga keseimbangan lingkungan tempat huni masyarakat tersebut.

\section{Metode}

Penelitian ini dilakukan di Pulau Sabu yang merupakan wilayah dari daerah Kabupaten Kupang di Nusa Tenggara Timur. Salah satu desa di Kecamatan Sabu Barat yaitu desa Raeloro merupakan desa tempat Kampung adat Namata berada dengan jarak desanya sekitar $\pm 3 \mathrm{Km}$ dari Kota Seba (Gambar 2). Kampung Namata berdiri dengan kekerabatan dua Suku, yakni Suku Namata dan Nataga ciri bangunan rumah adat yang berada di Kampung ini.

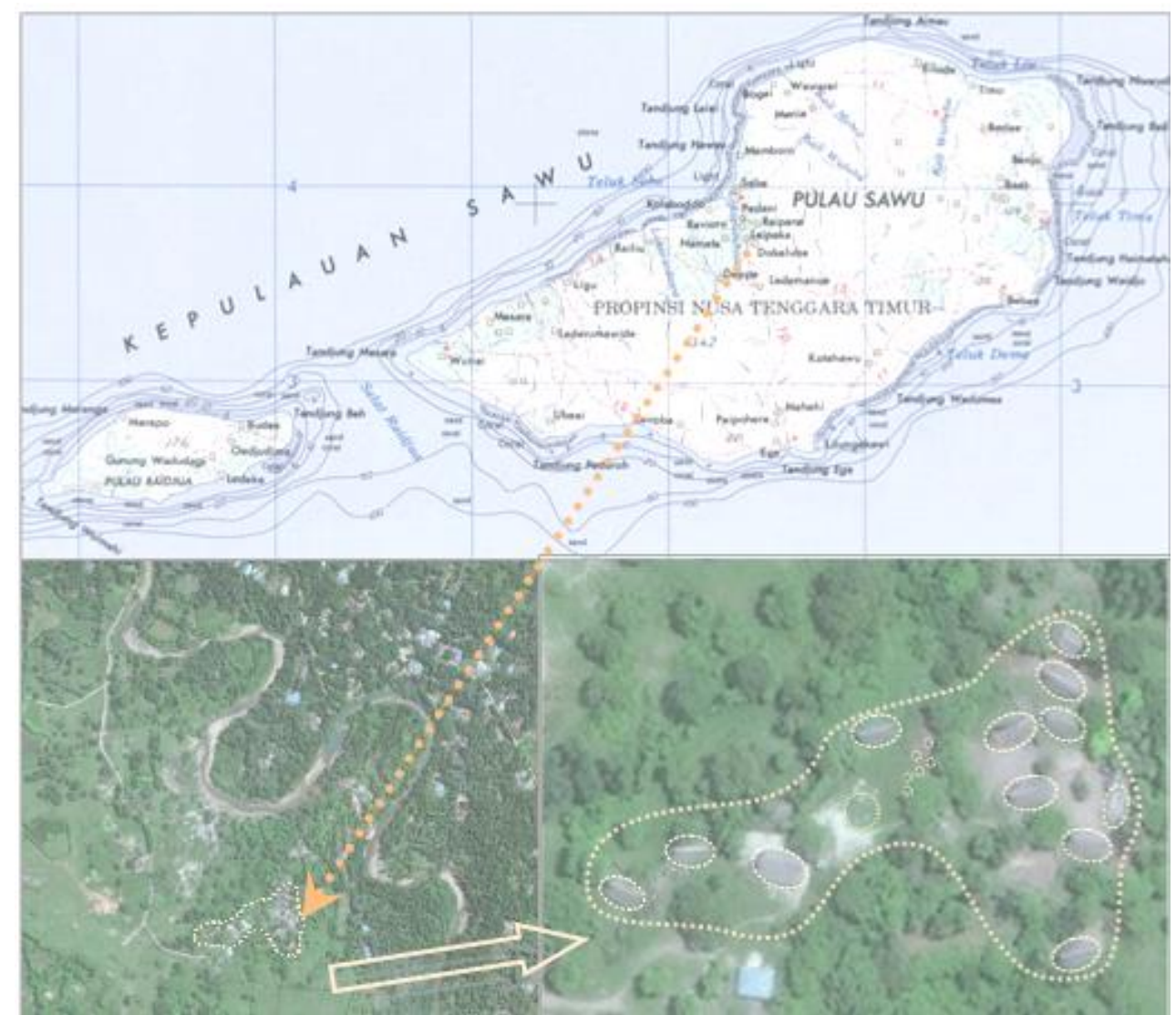

Gambar 2. Peta Wilayah Kecamatan Sabu dan Lokasi Kampung Adat Namata

Sumber: Kabupaten Sabu Raijua Vector \& http://www.bing.com/maps/ dalam Kapilawi, 2015

Arsitektur yang berkelanjutan memiliki pengertian yaitu arsitektur yang memenuhi kebutuhan saat ini, tanpa membahayakan kemampuan generasi yang akan datang dalam memenuhi kebutuhan mereka sendiri. Kebutuhan ini tentu berbeda dari satu masyarakat ke masyarakat lain, dari satu kawasan ke kawasan lain dan paling baik bila ditentukan oleh masyarakat terkait (Steele, 1997; Noviana, 2013). Penelitian ini dilakukan dengan metode pendekatan deskriptif kualitatif untuk mempelajari prosesi berkonstruksi dalam masyarakat adat di kampung Namata berdasakan perolehan data, situasi-situasi tertentu, kegiatan-kegiatan, sikap-sikap, pandangan-pandangan, serta prosesproses yang sedang berlangsung saat ritual adat berkonstruksi dilakukan.

Hasil wawancara dan observasi sebagai data langsung terhadap setiap tahapan proses ritual atau tradisi berkonstruksi pada setiap elemen bangunan atau bagian konstruksi rumah tradisionalnya. Data yang didapat kemudian dianalisis dengan menggunakan metode deskriptif untuk mendeskripsikan gejala dan peristiwa yang terjadi selama proses berkonstruksi masyarakat adat di Kampung Adat Namata. Pada proses ini peristiwa berkonstruksi menjadi pusat perhatiannya dan 
kemudian dipaparkan sebagaimana adanya. Sesuai dengan pendekatan kualitatif (Yusuf, 2016) yang bermaksud untuk melihat dan mengungkapkan keadaan maupun objek serta menemukan makna dari pemahaman yang mendalam maka dalam hal ini merupakan pemahaman masyarakat adat mengenai keberlanjutan tradis berkonstruksi. Tahap-tahap ini diharapkan dapat mengungkapkan situasi, budaya atau tradisi yang selama ini dilakukan oleh warga masyarakat Sabu di kampung adat Namata secara keseluruhan, khususnya dalam kegiatan tata cara ritual penyelesaian konstruksi rumah tradisional pada ritual membangun rumah adat dan bagaimana masyarakat dapat memahami penyelesaian dengan teknologinya terhadap budaya berkonstruksi setempat dalam arsitektur tradisionalnya.

\section{Hasil dan Pembahasan}

Kampung adat Namata terbentuk dari kesepakatan setiap suku-suku yang berkompeten untuk menetapkan nama Namata sebagai tempat peradaban suku mereka. Pada masa penjajahan pernah dikeluarkan larangan terhadap masyarakat dan tokoh-tokoh masyarakat saat itu untuk tidak boleh mengenyam dunia pendidikan hingga pada masa akhir penjajahan. Kemudian larangan itu mulai berangsur tiada dan saat penjajahan mulai beranjak tiada, maka masyarakat pun sudah boleh mengenyam dunia pendidikan, tapi dengan ketentuan bahwa yang boleh mengenyam atau yang boleh bersekolah adalah setiap orang yang masih merupakan keturunan dalam kelembagaannya memiliki posisi sebagai raja (keturunan raja-raja) dan pemangku adat, yakni dalam hal ini Suku Namata dan Nataga. Sehingga dalam perkembangannya kekerabatan suku ini lebih cenderung dikenal terlebih dahulu dikalangan masyarakat luar sebagai salah satu suku yang pertama dan tertua di Seba.

Kampung adat Namata sejak terbentuknya sampai dengan sekarang, selalu memegang teguh kekerabatan kekeluargaannya dalam bentuk kebersamaan dalam keluarga sebagai saudara bersaudara dalam suatu wilayah komunitas. Kebersamaan ini ditandai dengan keberadaan rumah-rumah adat dari masing suku, seperti suku Namata, suku Nataga, suku Nahupu dan suku Nahoro. Ini ditandai dengan adanya suatu kompleks tempat lingkungan binaan dari keempat Suku dengan kompleks rumah adat masing-masing.

Pada dasarnya, rumah orang Sabu didirikan di atas 8 (delapan) tiang atau 10 (sepuluh) tiang. Dengan dua cara bentuk kontruksi pondasi, yakni sebagian tiang ditanam dalam tanah, ataupun hanya diletakkan di atas batu bulat pipih. Penempatan setiap tiang konstruksi selalu diikuti dengan material tambahan berwujud benda-benda yang telah melalui proses ritual serta tradisi sembelih dan dua orang yang makan makanan khas Pulau Sabu (Kacang hijau dan gula Sabu) dan berdiri pada arah posisi rumah bagian timur dan barat dan tradisi lainnya yang berkaitan dengan penempatan material konstruksi. Satu rumah terdiri dari dua ruangan, yaitu ruang Wui dan Duru juga terdapat dua tiang, yakni tiang terru Wui dan terru Duru. Pada bagian muka setiap ruang terdapat pintu masuk dan teras atau bale-bale tempat menerima tamu yang disebut Kelaga Rai. Bagian belakang dari ruang Wui terdapat dapur dan loteng untuk penyimpanan bahan makanan dan benda-benda kebutuhan wanita (benang pemintal, kain tenunan), dengan kekhususan ruang Wui dan loteng ini hanya diperbolehkan bagi kaum wanita yang memasukinya (Detaq, 1973:44-45).

Arsitektur rumah orang Sabu termasuk didalamnya rumah adat di Kampung Adat Namata yaitu Aтти Rahi Hawu dapat disimpulkan sebagai arsitektur dengan sifat ke-lokal-an dan dapat diketegorikan sebagai arsitektur vernakular. Mentayani dkk (2012) merangkum dari pandangan ahli menyebutkan bahwa arsitektur vernakular merupakan desain arsitektur yang telah menyesuaikan dengan iklim lokal, menggunakan teknik serta material lokal, dipengaruhi oleh aspek budaya dan ekonomi masyarakat setempat. Rumah adat di Kampung Namata memiliki keunikan sendiri terutama dari segi keberlanjutan berkonstruksi dan pemahaman akan filosofi serta makna yang terkandung dalam tiap elemen bangunan. Sesuai dengan pendapat Koentjaraningrat (2009) pada rumah adat ini juga terjadi penyelesaian teknologi dalam membangun rumah, bentuk dan model bangunan cenderung memilih bentuk rumah bertiang ataupun di atas tiang (pile dwelling), dimana sistem 
sambungan menggunakan material dari jenis material lokal setempat, mulai dari pondasi, dinding maupun alat penyambung konstuksi.

\section{Rumah Tradisional Ammu Rahi Hawu}

Salah satu bangunan tradisional masyarakat yaitu Amти Rahi Hawu merupakan bangunan tradisional yang telah menjadi situs bangunan rumah adat masyarakat Sabu. Dituturkan oleh Bapak Isbozet Radja Pono (wawancara, 2020) bahwa Rumah adat ini terakhir dikelolah atau dijaga oleh pihak keluarga Leba Alu yang ada dalam tatanan struktur kehidupan suku-suku, yakni dari suku Namata. Rumah ini oleh masyarakat Sabu Seba merupakan rumah induk dari ke empat suku besar, yakni suku Namata, suku Nataga, suku Nahoro dan suku Nahupu.

Dalam keseharian, Атти Rahi Hawu digunakan sebagai rumah tinggal bagi kalangan masyarakat adat. Oleh masyarakat Sabu, secara struktur konstruksi Ammu Rahi Hawu juga dikenal dengan istilah Aтти Halla atau rumah tanam. Disebut rumah tanam oleh karena pada umumnya pemasangan tiang-tiang konstruksi sistem pondasi langsung ditancapkan ke dalam tanah. Tiang-tiang konstruksi tersebut menggunakan material kayu yaitu kayu Kolla yang memiliki kekuatan dan tahan terhadap cuaca serta pelapukan dari rayap kayu. Sehingga kayu Kolla dipilih dan dipakai untuk konstruksi pondasi rumah dalam jangka waktu yang cukup lama (Gambar 3).

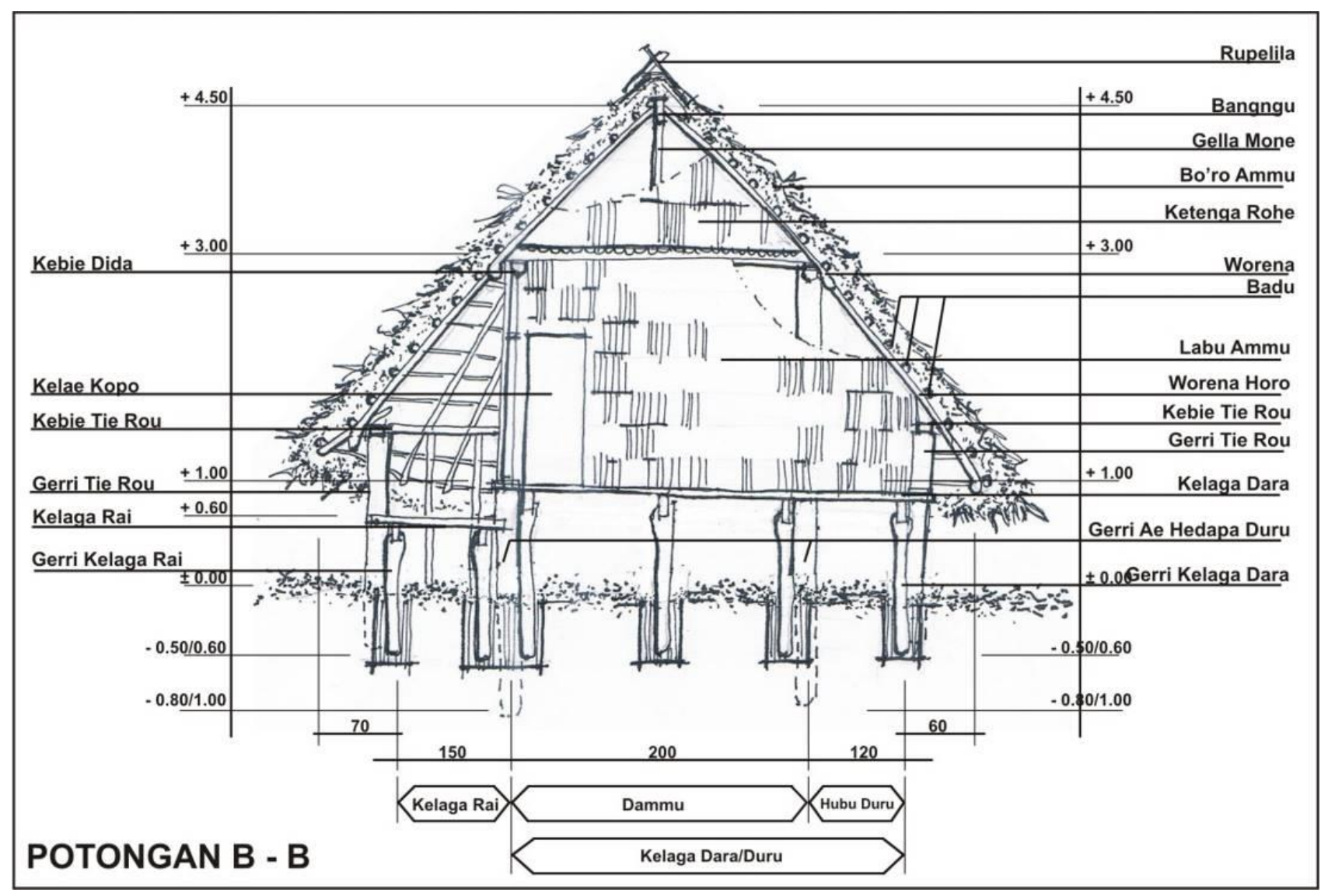

Gambar 3. Ammu Rahi Hawu Sebagai Rumah Tanam (Ammu Halla)

Sumber: Kapilawi, 2015 


\section{Tahapan Tradisi Penyelesaian Konstruksi Rumah Adat Ammu Rahi Hawu A. Tahap Sosialisasi Penentuan Syarat Perbaikan Rumah Adat}

Tabel 1. Sosialisasi Penentuan Syarat Perbaikan Rumah Adat

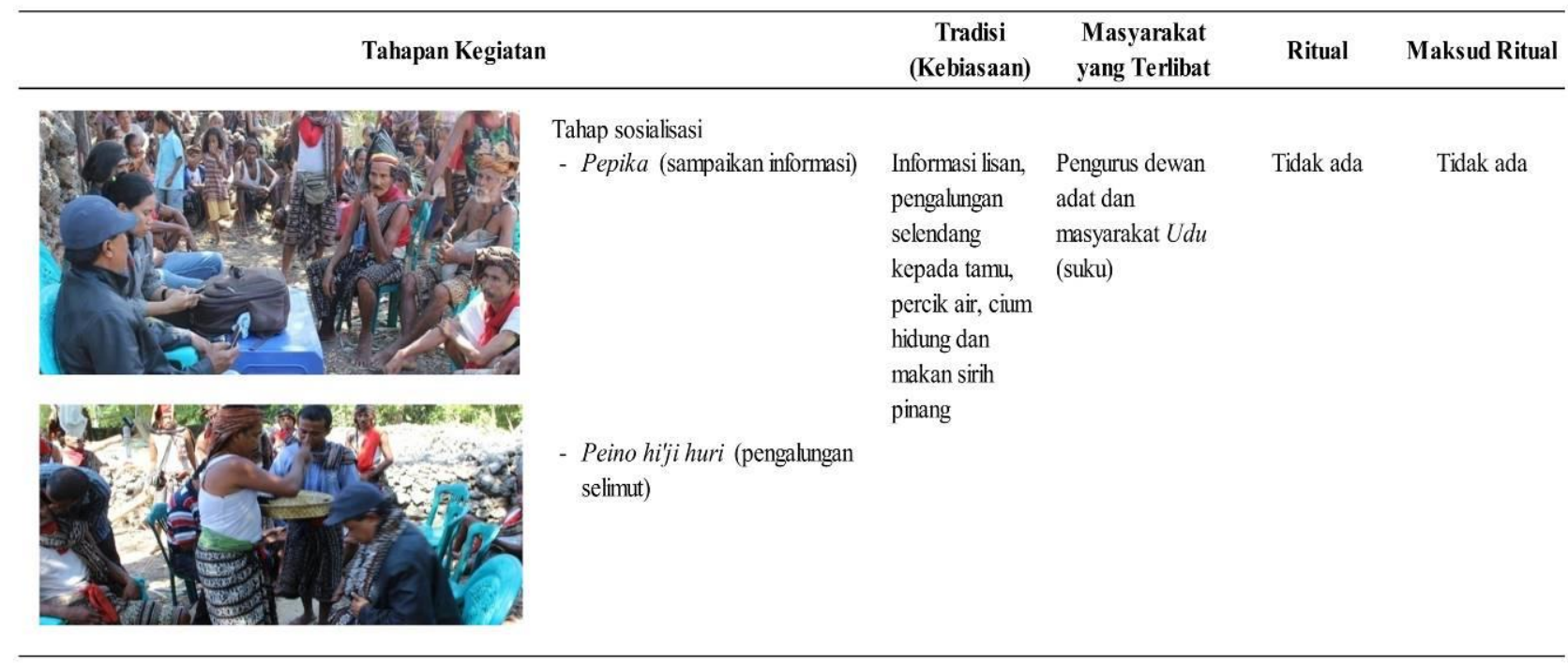

Sumber: Analisis, 2020

Aktivitas tradisi yang terjadi pada tahapan ini, tanpa diikuti dengan ritual tapi hanya bersifat syukuran yang turun-temurun sering dilakukan dan sampai saat ini masih dijaga dengan baik. Kegiatan sosialisasi penentuan syarat perbaikan rumah adat menandakan bahwa perencanaan pelestarian budaya fisik oleh pemerintah diterima dengan baik oleh masyarakat (Tabel 1).

\section{B. Tahap tradisi dalam bermusyawarah}

Berkumpul sudah menjadi kebiasaan pada masyarakat adat di lokasi penelitian, menandai suatu bentuk kebersamaan dengan saling berinteraksi dengan sesama kelompok dari kelompok suku lainnya. Tahapan ini juga ditandai dengan suatu bentuk kebersamaan secara kekeluargaan antara pemerintah, pengurus dewan adat dan masyarakat $U d u$ (suku). Dengan demikian dalam tahapan musyawarah ini tradisi atau kebiasaan yang terjadi dalam bentuk simbol kebersamaan, yakni makan Sirih Pinang bersama tanpa ritual khusus yang menandai kegiatan ini.

\section{Tradisi Pembongkaran Ammu}

Tahapan ini ditandai dengan suatu bentuk kebersamaan dengan makan bersama sebelum memulai kegiatan pembongkaran dengan beberapa ritual yang harus dijalani dan beberapa aktivitas lainnya. Setelah tahap kegiatan sebelum pembongkaran dilaksanakan, tahap selanjutnya adalah tahap pemilihan atau pencarian material rumah adat. Pada tahapan ini juga ditandai dengan melakukan ritual memberi makan pada pohon yang terpilih untuk diambil dan yang akan dijadikan material konstruksi rumah. Pemilihan bahan material kayu ini dilakukan dengan memperhatikan umur dari pohon yang akan diambil dan dan tentunya secara pemahaman masyarakat adat, yakni kayu yang telah memenuhi syarat dengan jawaban atas setiap ritual melalui media ritual yang dilakukan. 
Tabel 2. Tradisi Sebelum Pembongkaran dan Pemilihan/Pencarian Material Rumah Adat

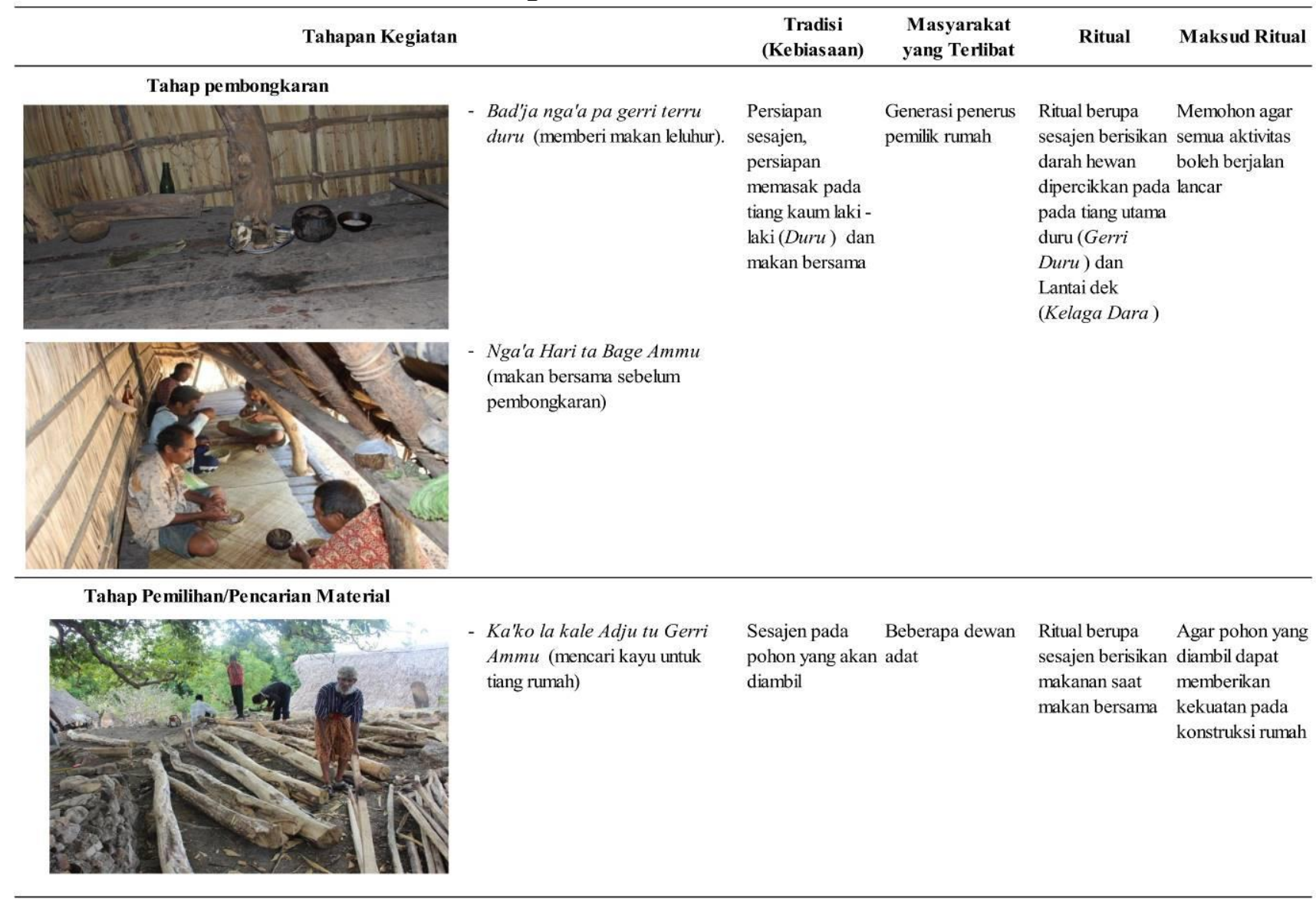

Sumber: Analisis, 2020

\section{Tradisi Pelaksanaan Pembangunan Awal}

Tahap pertama pada tradisi pelaksanaan pembangunan awal adalah pemasangan pondasi dan tiang-tiang konstruksi Ammu Rahi Hawu.

Tabel 3. Tradisi Sebelum Pelaksanaan Tiang Konstruksi

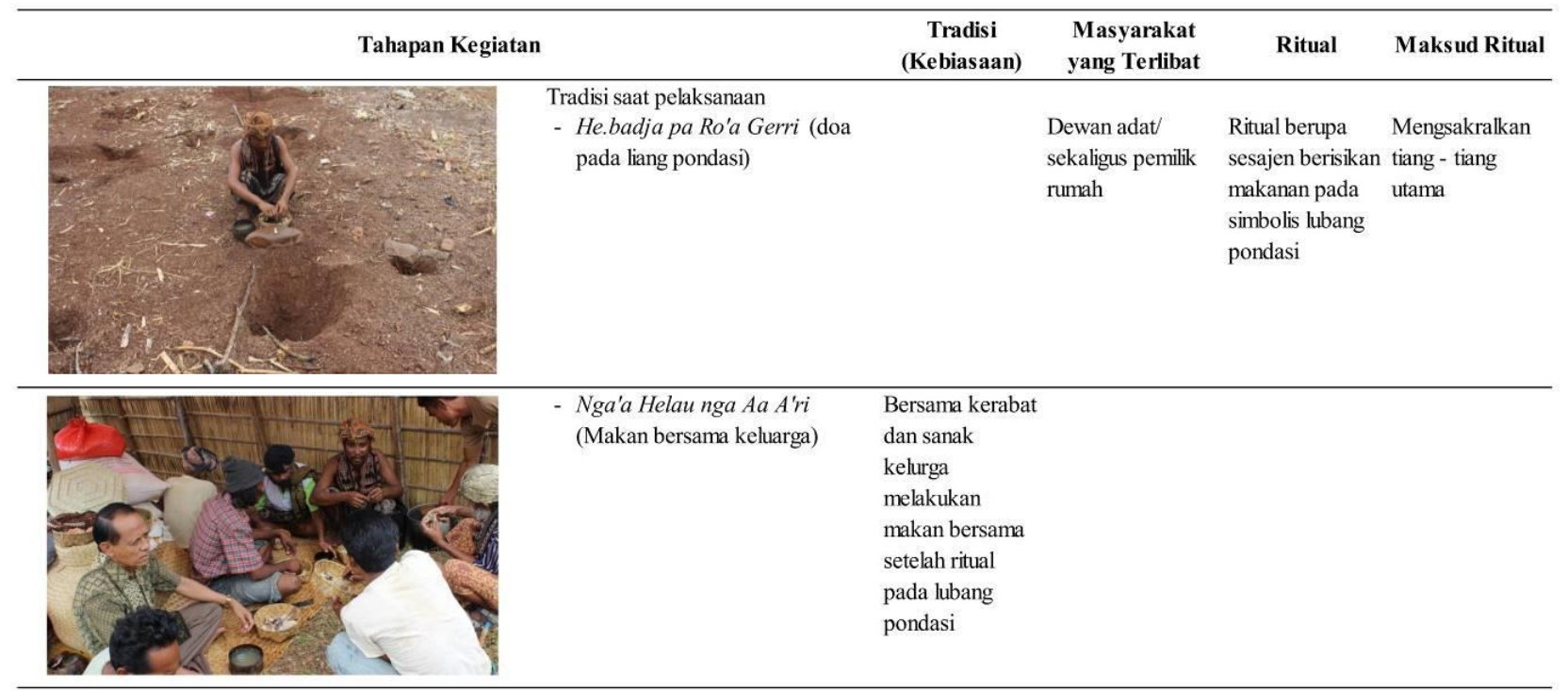

Sumber: Analisis, 2020 
Kebiasaan ini ditandai dengan sembelihan hewan serta kebiasaan makan bersama sebagai simbol kebersamaan dalam kekeluargaan dan aturan tradisi penurunan bagian konstruksi. Kegiatan ini diikuti dengan ritual adat sebagai pelengkap tradisi kepercayaan lalu dilanjutkan tahapan pemasangan bagian struktur utama pada tengah konstruksi rumah adat yaitu konstruksi tiang dan balok pada kayu-kayu tiang dan bagian konstruksi paling atas dari rumah adat (tabel 4).

Tabel 4. Tahap Pelaksanaan Konstruksi Tiang dan Balok

\begin{tabular}{|c|c|c|c|c|c|}
\hline Tahapan Kegiatan & & $\begin{array}{c}\text { Tradisi } \\
\text { (Kebiasaan) }\end{array}$ & $\begin{array}{c}\text { Masyarakat } \\
\text { yang Terlibat }\end{array}$ & Ritual & Maksud Ritual \\
\hline 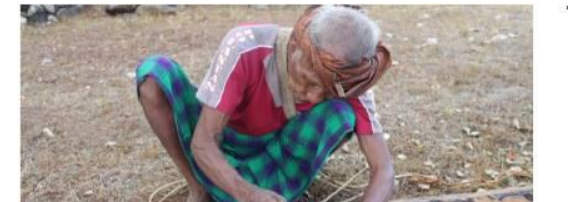 & $\begin{array}{l}\text { Tahap pelaksanaan } \\
\text { - Ak'ki dari pa Bangngu } \\
\text { (mengikat tali pada balok } \\
\text { bubungan) }\end{array}$ & $\begin{array}{l}\text { Mengikat untuk } \\
\text { menjaga } \\
\text { keseimbangan } \\
\text { balok nok } \\
\text { (Bangngu) }\end{array}$ & Dewan adat & Tidak ada & Tidak ada \\
\hline & - Halla Gerri (tanam tiang) & & $\begin{array}{l}\text { Dewan adat } \\
\text { dibantu masyarakat } \\
\text { adat }\end{array}$ & Tidak ada & Tidak ada \\
\hline & $\begin{array}{l}\text { - Pa'ha Kebie Dida (pasang } \\
\text { balok loteng) }\end{array}$ & $\begin{array}{l}\text { Pemasangan } \\
\text { serempak } \\
\text { menjaga } \\
\text { keseimbangan }\end{array}$ & $\begin{array}{l}\text { Dewan adat } \\
\text { dibantu masyarakat } \\
\text { adat }\end{array}$ & Tidak ada & Tidak ada \\
\hline
\end{tabular}

Sumber: Analisis, 2020

Tahapan pelaksanaan khusus bagian struktur utama dari konstruksi rumah adat ini, yakni pemasangan kayu-kayu tiang tentunya menjadi dasar dari struktur konstruksi rumah adat. Berikut gambar yang menunjukkan hasil dan bagian dari konstruksi rangka tiang dan balok loteng.

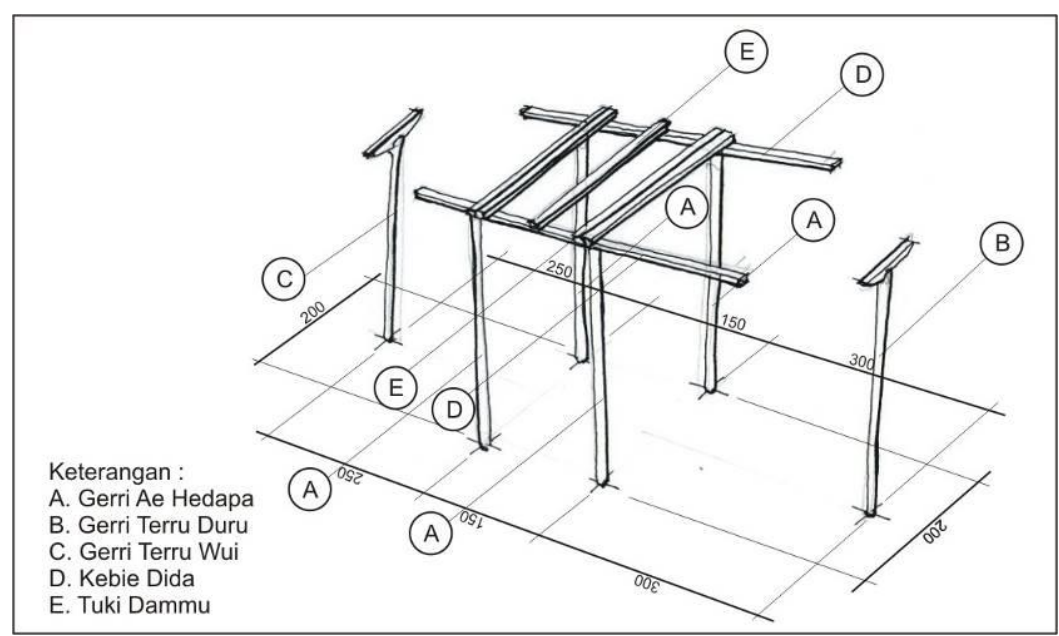

Gambar 4. Sketsa Bagian Konstruksi Rangka Tiang dan Balok Loteng Ammu Rahi Hawu Sumber: Kapilawi, 2015 
Tahap Pemasangan Balok Loteng dan Balok Pelengkung Ammu Rahi Hawu

Tahap selanjutnya setelah penyelesaian konstruksi rangka tiang dan balok loteng adalah pemasangan balok loteng dan balok pelengkung. Berikut tabel 5 yang menjelaskan tahapan kegiatan pelaksanaan pemasangan

Tabel 5. Tahapan Pelaksanaan Balok Pelengkung

\begin{tabular}{|c|c|c|c|c|c|}
\hline Tahapan Kegiatan & & $\begin{array}{c}\text { Tradisi } \\
\text { (Kebiasaan) }\end{array}$ & $\begin{array}{c}\text { Masyarakat } \\
\text { yang Terlibat }\end{array}$ & Ritual & Maksud Ritual \\
\hline $2-\lambda$ & $\begin{array}{l}\text { Tahap pelaksanaan } \\
\text { - Paha Taga Batu Duru (pasang } \\
\text { balok pelengkung pada kaum laki } \\
\text { - laki) } \\
\text { - Paha Taga Batu Duru (pasang } \\
\text { balok pelengkung pada kaum } \\
\text { perempuan) }\end{array}$ & Gotong - royong & 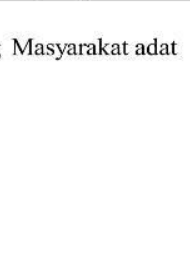 & Tidak ada & Tidak ada \\
\hline $1>$ & $\begin{array}{l}\text { - He'badja pa Gerri Terru } \\
\text { (berdoa pada tiang utama) }\end{array}$ & $\begin{array}{l}\text { Menyajikan } \\
\text { makanan untuk } \\
\text { ritual }\end{array}$ & $\begin{array}{l}\text { Dewan } \\
\text { adat/sekaligus } \\
\text { pemilik rumah. }\end{array}$ & $\begin{array}{l}\text { Ritual pada tiang } \\
\text { utama setelah } \\
\text { pemadatan tiang }\end{array}$ & $\begin{array}{l}\text { Harapan agar } \\
\text { tiang tetap berdiri } \\
\text { kokoh }\end{array}$ \\
\hline & $\begin{array}{l}\text { - Dui ru Ammu (ambil daum } \\
\text { rumah) }\end{array}$ & $\begin{array}{l}\text { Aturan tentang } \\
\text { sanksi saat } \\
\text { mobilisasi daun } \\
\text { rumah tidak } \\
\text { boleh menyentuh } \\
\text { tanah }\end{array}$ & $\begin{array}{l}\text { Masyarakat adat } \\
\text { terutama kaum } \\
\text { wanita. }\end{array}$ & Tidak ada & Tidak ada \\
\hline
\end{tabular}

Sumber: Analisis, 2020

Balok pelengkung (Taga Batu) merupakan simbol kehidupan antara kaum laki-laki dan kaum perempuan. Dimana keberadaan balok pelengkung merupakan penentu akan keberadaan ruang bagi kaum laki-laki dan kaum perempuan dalam rumah (Gambar 5).

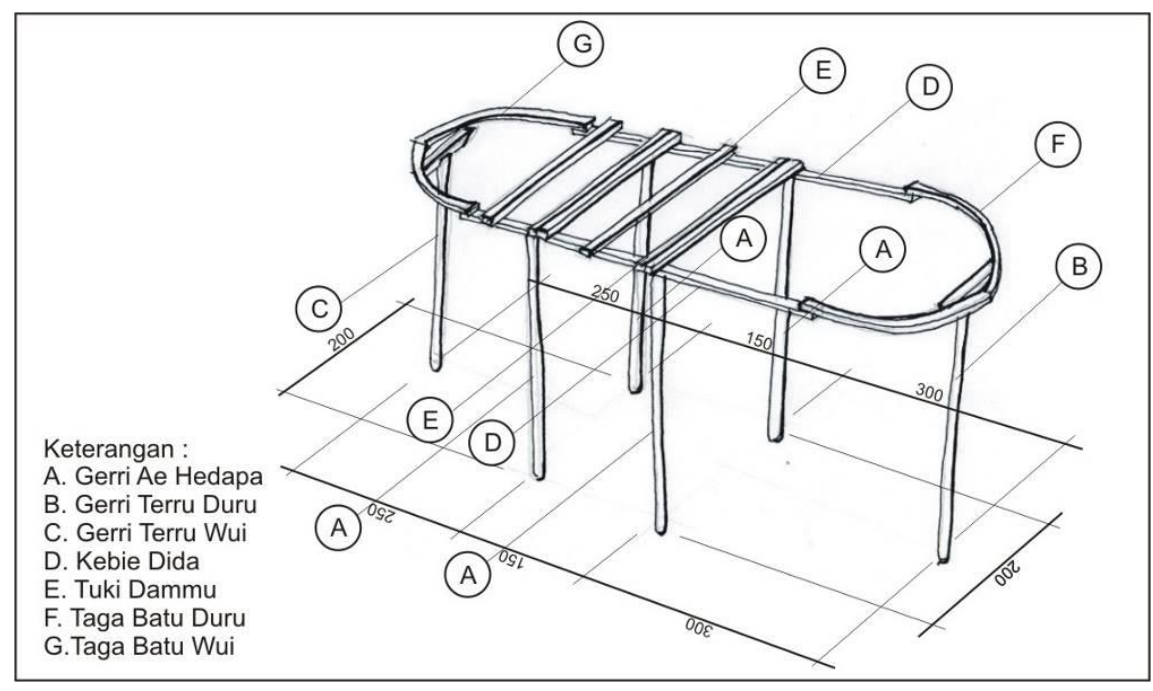

Gambar 5. Sketsa Bagian Konstruksi Balok Loteng Ammu Rahi Hawu Sumber: Kapilawi, 2015 
Tahap Pemasangan Tiang dan Balok Atap Ammu Rahi Hawu

Tahap pelaksanaan ini mencakup bagian konstruksi untuk memulai kerangka atap yang diikuti dengan aktivitas pemasangan balok nok bubungan dan pemasangan kayu kaso sebagai berikut.

Tabel 6. Tahapan Pelaksanaan Balok Nok Bubungan (Bangngu)

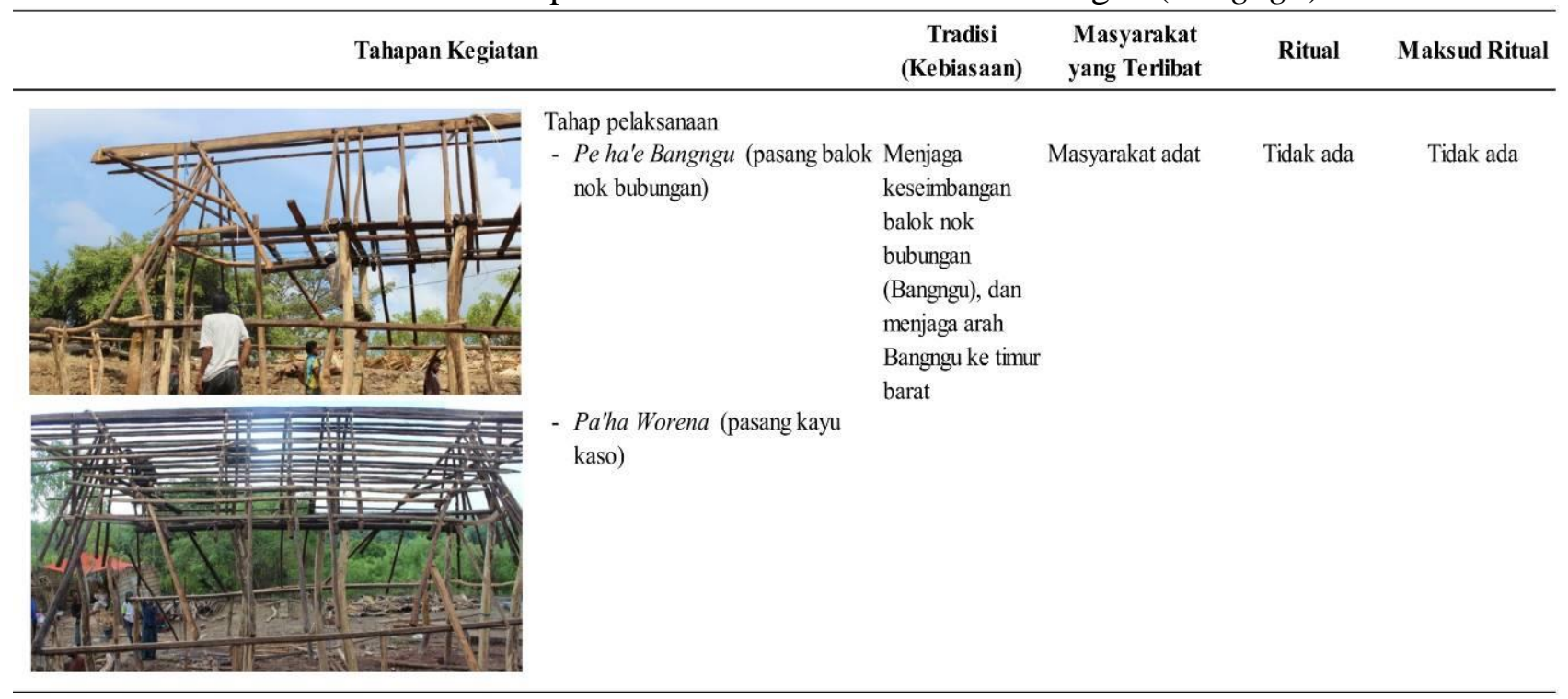

Sumber: Analisis, 2020

Penyelesaian pada bagian konstruksi ini, hanya dibutuhkan tenaga dan kekompakan dalam menyelesaikan pemasangan sistem konstruksi dengan pertimbangan aturan tradisi yang harus dilaksanakan. Hal ini menyimbolkan keseimbangan bentuk kehidupan di dalam rumah. Bagianbagian dari konstruksi rangka atap bubungan dapat dilihat pada gambar di bawah ini.

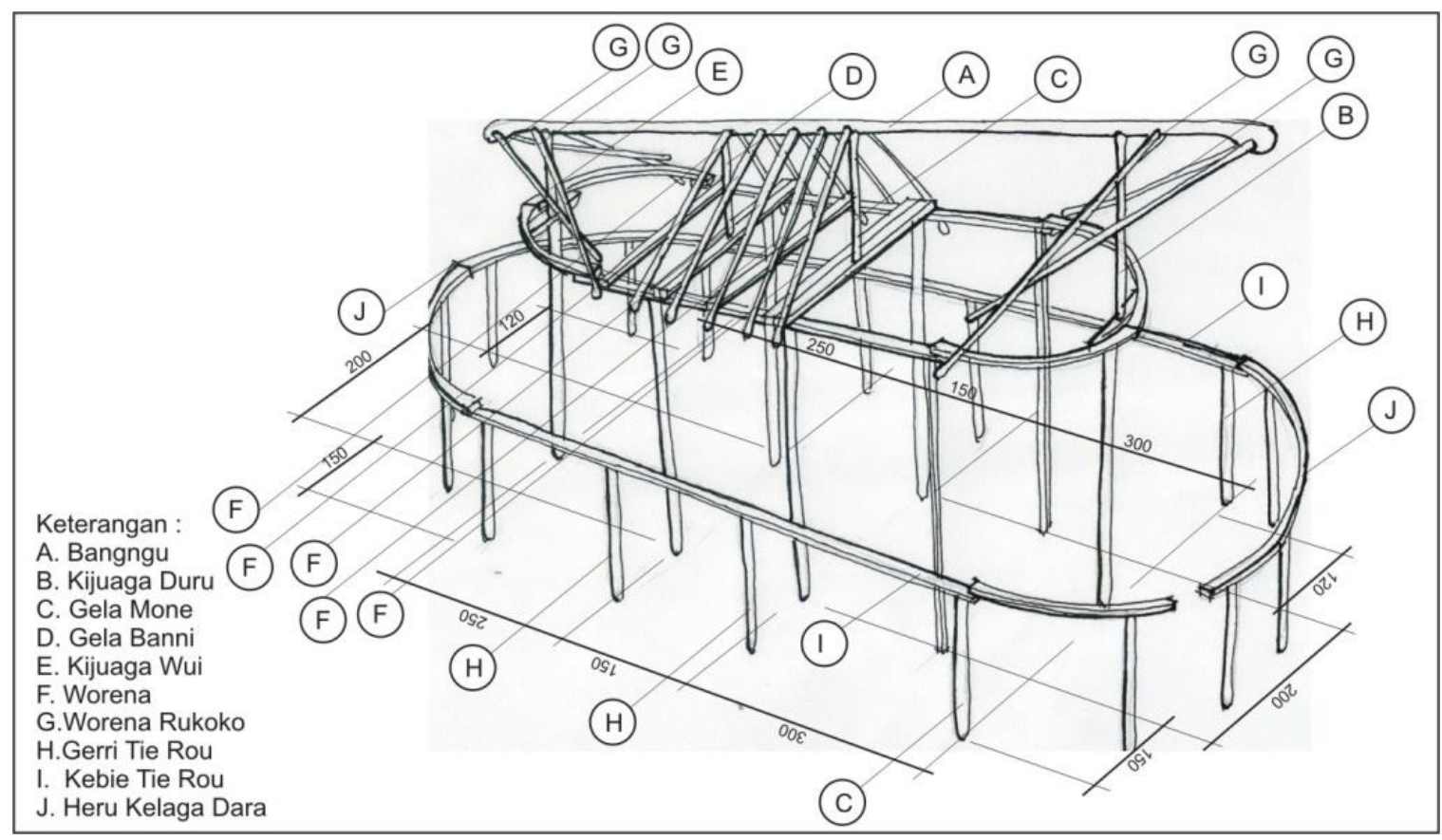

Gambar 6. Sketsa Bagian Konstruksi Rangka Atap Bubungan Ammu Rahi Hawu Sumber: Kapilawi, 2015 
Tahap Pemasangan Rangka Atap/Kaso Ammu Rahi Hawu

Tahap pelaksanaan pemasangan rangka atap/kaso, yakni kelanjutan dari bagian konstruksi untuk rangka atap sebagai penyambungan dari konstruksi sebelumnya. Tahap-tahap kegiatan adalah sebagai berikut (tabel 7).

Tabel 7. Tahapan Pelaksanaan Rangka Atap/Kaso (Worena)

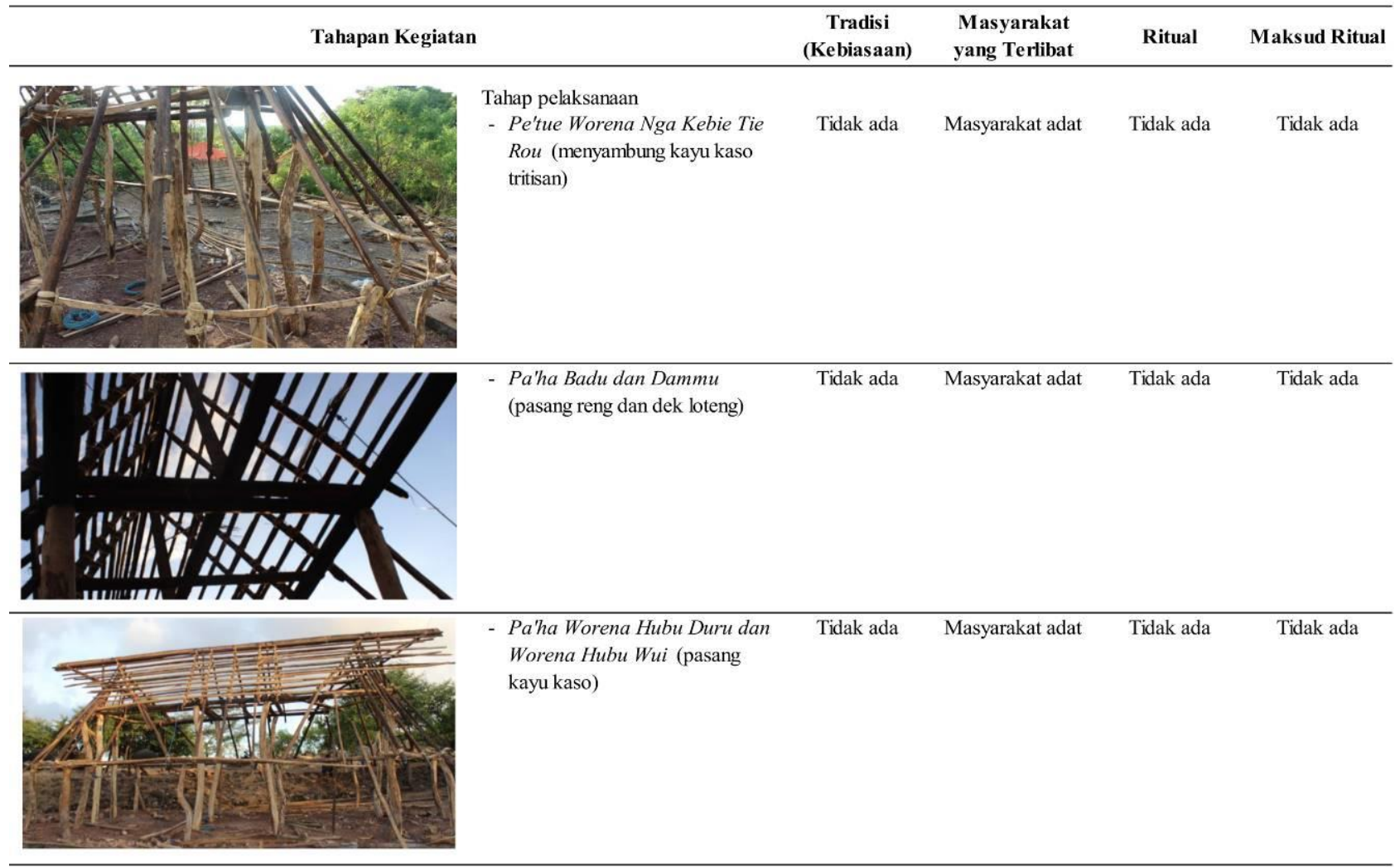

Sumber: Analisis, 2020

Untuk memperjelas bagian rangka atap, maka berikut sketsa yang memperlihatkan bentuk dan bagian-bagian dari rangka atap setelah pemasangan tersebut selesai dilaksanakan.

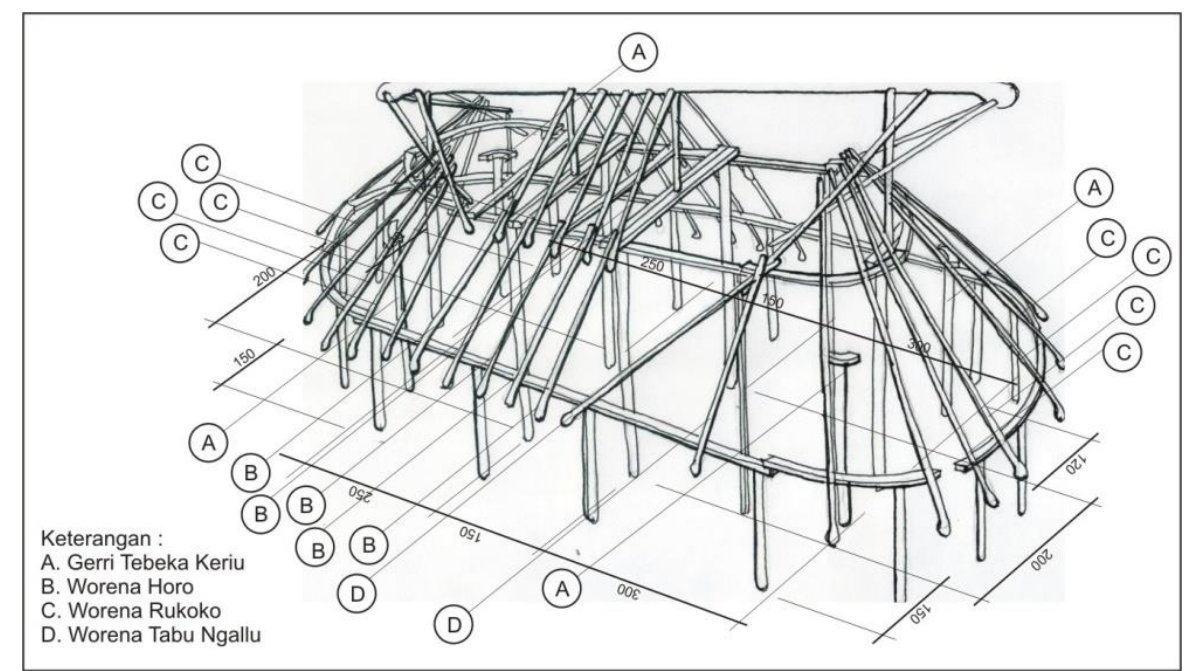

Gambar 7. Sketsa Bentuk dan Bagian dari Konstruksi Rangka Atap/Kaso Ammu Rahi Hawu Sumber: Kapilawi, 2015 


\section{Tahap Penutup Rangka Atap Ammu Rahi Hawu}

Tahap penutupan rangka atap dengan menggunakan daun lontar merupakan bagian konstruksi terakhir penyelesaian dimana aktivitas didasarkan pada ketetapan-ketetapan tradisi dan ritual yang mewarnai disetiap bagian-bagian konstruksi demi kehidupan manusia didalamnya yang lebih sehat.

Tabel 8. Tahapan Pelaksanaan Atap Rumah

\begin{tabular}{|c|c|c|c|c|c|}
\hline \multicolumn{2}{|l|}{ Tahapan Kegiatan } & \multirow{2}{*}{\begin{tabular}{l}
\multicolumn{1}{c}{$\begin{array}{c}\text { Tradisi } \\
\text { (Kebiasaan) }\end{array}$} \\
$\begin{array}{l}\text { Simbol bendera } \\
\text { kain tenunan } \\
\text { pembatasWui } \\
\text { dan Duru }\end{array}$
\end{tabular}} & \multirow{2}{*}{$\begin{array}{c}\begin{array}{c}\text { Masyarakat } \\
\text { yang Terlibat }\end{array} \\
\begin{array}{c}\text { Dewan adat dan } \\
\text { masyarakat adat }\end{array}\end{array}$} & \multirow{2}{*}{$\begin{array}{c}\text { Ritual } \\
\text { Tidak ada }\end{array}$} & \multirow{2}{*}{$\begin{array}{c}\text { Maksud Ritual } \\
\text { Tidak ada }\end{array}$} \\
\hline 7 & $\begin{array}{l}\text { Tahap pelaksanaan } \\
\text { - Padji (simbol memulai pasang } \\
\text { daun rumah) }\end{array}$ & & & & \\
\hline 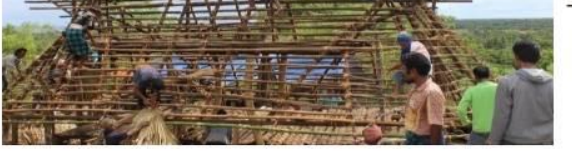 & $\begin{array}{l}\text { - Kut'tu Ru Hubi Hiu (anyam } \\
\text { daum lontar jadi } \\
\text { Rupelila /penutup bubungan) }\end{array}$ & $\begin{array}{l}\text { Anyam lontar } \\
\text { bubungan, } \\
\text { dilakukan oleh } \\
\text { satu keturunan } \\
\text { suku yang sama }\end{array}$ & $\begin{array}{l}\text { Masyarakat adat } \\
\text { keturunan }\end{array}$ & Tidak ada & Tidak ada \\
\hline & $\begin{array}{l}\text { - Bo'ro Ammu (pemasangan daun } \\
\text { rumah) }\end{array}$ & $\begin{array}{l}\text { Gotong - royong } \\
\text { masyarakat } \\
U d u / \text { suku }\end{array}$ & $\begin{array}{l}\text { Dewan adat dan } \\
\text { masyarakat adat }\end{array}$ & Tidak ada & Tidak ada \\
\hline & $\begin{array}{l}\text { - Pe ha'e Rukoko (pemasangan } \\
\text { leher daun) }\end{array}$ & $\begin{array}{l}\text { Serempak } \\
\text { pasang rukoko } \\
\text { Wui dan Duru }\end{array}$ & $\begin{array}{l}\text { Dewan adat dan } \\
\text { masyarakat adat }\end{array}$ & $\begin{array}{l}\text { Ritual simbol } \\
\text { kelapa, ayam, } \\
\text { parang dan } \\
\text { selendang }\end{array}$ & $\begin{array}{l}\text { Sebagai napas } \\
\text { kehidupan dalam } \\
\text { rumah }\end{array}$ \\
\hline & $\begin{array}{l}\text { - Heba'dja Any'nyu Ketanga } \\
\text { Rohe (doa memulai pasang } \\
\text { dinding loteng) } \\
\text { - Pa'ha Ketanga Rohe (pasang } \\
\text { dinding loteng) }\end{array}$ & Tidak ada & $\begin{array}{l}\text { Dewan adat } \\
\text { pemilik rumah dan } \\
\text { dibantu masyarakat } \\
\text { adat }\end{array}$ & $\begin{array}{l}\text { Ritual pada } \\
\text { bagian daun leher } \\
\text { (Rukoko), pada } \\
\text { bagian kaum laki. } \\
\text { laki (Duru) }\end{array}$ & $\begin{array}{l}\text { Sebagai pertanda } \\
\text { selesainya } \\
\text { kegiatan tutup } \\
\text { daun rumah } \\
\text { dengan tidak ada } \\
\text { halangan }\end{array}$ \\
\hline
\end{tabular}

Sumber: Analisis, 2020

Bagian-bagian dari konstruksi pada rangka atap dan penutup atap Ammu Rahi Hawu dapat dilihat pada sketsa di bawah ini.

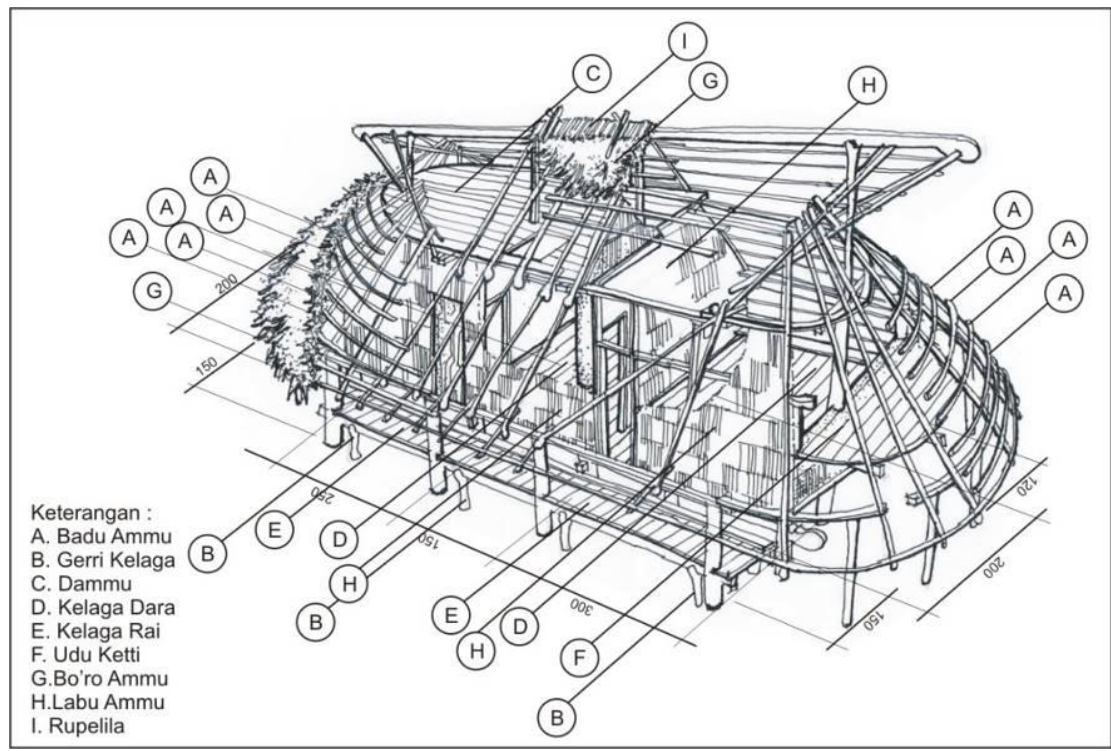

Gambar 8. Sketsa Bagian-Bagian dari Rangka Atap dan Penutup Atap Ammu Rahi Hawu Sumber: Kapilawi, 2015 


\section{Tahap Akhir Pembangunan}

Kegiatan pada tahap akhir pembangunan berupa pemasangan dinding dan makan bersama setelah kegiatan ini selesai. Kegiatan kemudian berlanjut pada pelumuran dek lantai dan kembali diakhiri sengan makan bersama. Untuk lebih jelas dapat dilihat pada tabel berikut.

Tabel 9. Tahapan Akhir Pembangunan

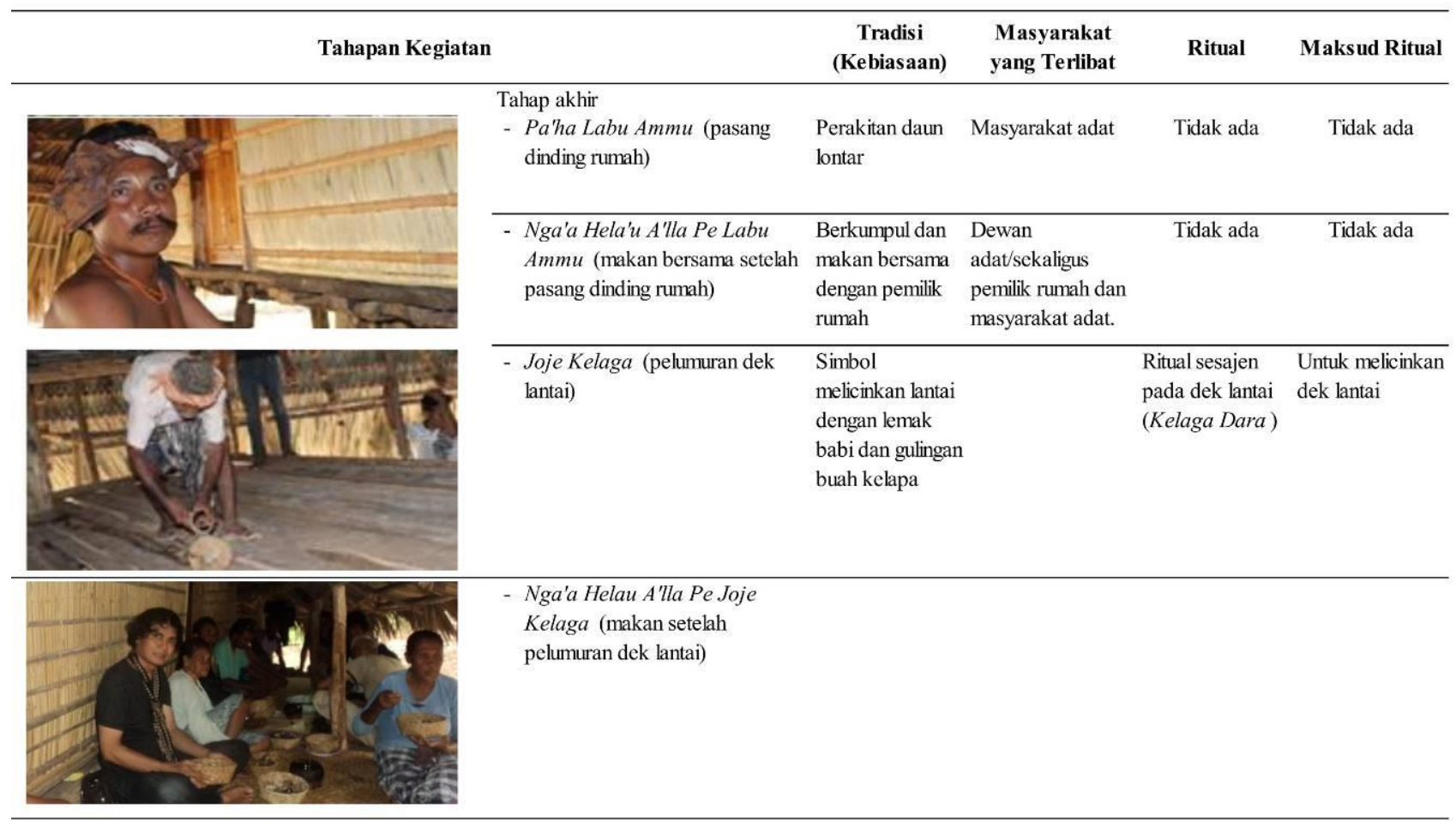

Sumber: Analisis, 2020

\section{E. Keberlanjutan Arsitektur Rumah Tradisional Sabu}

Keaslian bentuk, material konstruksi dan cara menyelesaikan konstruksi, merupakan ciri lokalitas dan merupakan keberlanjutan dari arsitektur rumah tradisional Sabu, dengan keragaman bentuk fisik namun memiliki kesamaan bentuk atap dan material yang masih asli yang diperoleh melalui kearifan masyarakat kampung adat Namata. Tampilan ciri arsitektur tradisional daerah Sabu dilakukan dengan cara mengadopsi beberapa filosofi bentuk berupa simbol-simbol dari artefak, dan dengan tata cara kebiasaan atau tradisi dalam berkonstruksi. Simbol bentuk artefak dan kesenian berupa ornamen nampak terlihat pada bagian-bagian konstruksi rumah tinggal masyarakat Sabu yang masih dalam satu keturunan dari kampung adat Namata di Sabu.

Ciri arsitektur tradisonal pada rumah adat Ammu Rahi Hawu selain dari ciri lokalitas dapat dilihat juga dari kepercayaan dan prosesi keagamaan untuk menghormati alam dan leluhur disetiap prosesi dan tata cara pelaksaan kegiatan berkonstruksi. Tidak hanya pada prosesi sifat ke-lokal-an sebagai ciri dari vernakular rumah adat ini terlihat pada penggunaan material disetiap bagian bangunan serta teknik berkonstruksi pada setiap tahap berkonstruksi yang sangat dipengaruhi oleh aspek budaya dan ekonomi masyarakat. Penyelesaian berkonstruksi juga memilih bentuk rumah bertiang. Oleh sebab itu, rumah adat Ammu Rahi Hawu di Kampung Namata memiliki keunikan sendiri terutama dari segi keberlanjutan berkonstruksi dan pemahaman akan filosofi serta makna yang terkandung dalam tiap elemen bangunan. 


\section{Kesimpulan}

Keberlanjutan dalam tradisi berkonstruksi rumah tradisional Sabu (Ammu Rahi Hawu) oleh masyarakat adat digambarkan dengan tata cara dalam prosesi pengambilan bahan bangunan sehingga tercipta bentuk bangunan dengan atap mengerucut dan berbahan daun yang memberikan kenyaman terhadap hunian rumah tradisional. Konstruksi rumah tradisional Атти Rahi Hawu dengan pondasi tanamnya (Атти Halla) dan dengan lantai dek papan dalam bentuk rumah panggung, dapat mengantisipasi kondisi alam Sabu Raijua yang beriklim tropis dengan suhu yang panas.

Tujuan dari keberlanjutan berkonstruksi dari setiap tata cara pelaksanaan adat atau tradisi berkonstruksi adalah sebagai bentuk tindakan menghormati masyarakat adat yang ditunjukan mulai dari tata cara ritual penebangan pohon, tata cara pengambilan bahan bangunan hingga penciptaan bentuk bangunan. Termasuk didalamnya unsur kearifan lokalitas dalam penggunaan material lokal, penamaan bagian rumah adat menggunakan unsur bahasa lokal serta pemahaman filosofi dan tata cara ritual tiap bagian konstruksi. Semua hal tersebut diatas adalah upaya dan pemahaman masyarakat adat demi menjaga keberlanjutan tata cara berkonstruksi dan keseimbangan terhadap lingkungan alam sekitarnya. Dengan demikian kearifan masyarakat adat di kampung adat Namata, dalam mempertahankan hidupnya selalu berpegang pada kearifan budaya tradisi membangun yang diwariskan dari generasi ke generasi dan dilakukan demi kelangsungan hidup.

\section{Daftar Acuan}

Ardiani, Y. M. (2015). Sustainable Architecture Arsitektur Berkelanjutan. Jakarta: Erlangga.

Detaq, Y. Y. (1973). Memperkenalkan kebudayaan suku bangsa Sawu. Nusa Indah.

Kapilawi, Y. W. D., Antariksa, A., \& Nugroho, A. M. (2015). Lokalitas Struktur Konstruksi Rumah Tradisional Sabu Di Kampung Adat Namata, NTT. RUAS (Review of Urbanism and Architectural Studies), 13(2), 60-66.

Kapilawi, Y. (2016). Lokalitas Arsitektur Dan Tradisi Membangun Rumah Tradisional Sabu Di Kampung Adat Namata NTT (Doctoral dissertation, Universitas Brawijaya).

Koentjaraningrat, K. (2009). Pengantar Ilmu Antropologi, Edisi Revisi PT. Rineka Cipta: Jakarta.

Mentayani, I., \& Muthia, P. R. (2012). Menggali Makna Arsitektur Vernakular: Ranah, Unsur, dan Aspek-Aspek Vernakularitas. LANTING Journal of Architecture, 1(2), 68-82. Done

Manurung, P. (2014). Arsitektur Berkelanjutan, Belajar Dari Kearifan Arsitektur Nusantara. Prosiding pada Simposium Nasional RAPI XIII-2014 FT Universitas Muhammadiyah Surakarta A75-81. ISSN, 1412-9612.

Noviana, M. (2013). Konsep Arsitektur Berkelanjutan Arsitektur Vernakular Rumah Lamin Suku Dayak Kenyah. Kreatif: Desain Produk Industri Dan Arsitektur, 1(1).

Nurdiah, E. A., \& Hariyanto, A. D. (2013). Struktur Rangka Atap Rumah Tradisional Sumba. http://repository.petra.ac.id/16221/1/056STRUKTUR_ATAP_SUMBA.pdf

Permana, A. Y. (2011). Penerapan Konsep Perancangan Smart Village Sebagai Local Genius Arsitektur Nusantara. Jurnal Arsitektur Komposisi, 9(1), 24-33.

Yusuf, A. M. (2016). Metode penelitian kuantitatif, kualitatif \& penelitian gabungan. Prenada Media. 